\title{
The Relationship Between Women Workforce Participation and the Growth Rate of Gross Domestic Product (A Case Study of Pakistan)
}

\author{
Dr. Sadaf Mustafa \\ Assistant Professor, Department of Commerce, University of Karachi \\ Ayesha Fareed \\ Lecturer, Department of Commerce, University of Karachi
}

\begin{abstract}
This study explains the impact of increase in the rate of women workforce participation on the growth rate of Gross Domestic Product (GDP), a case study of Pakistan. Women is the pillar of a society which decides the strength or weakness of a nation. The data for research is collected from Pakistan Bureau of Statistic. The period of research is 9 years from (2001 to 2013). Data for (2002-03, 2004-05 and 2011-12) is not available. Based on previous research, it is hypothesized that increase in the rate of women workforce will increase the growth rate of GDP of Pakistan in the respective period. The results are expressed as Correlation Matrix, Descriptive Statistics and Ordinary Least Square (OLS). After analysis of all these estimates it is concluded that there is a weak positive relationship between the variables. Around 10\% of GDP of Pakistan is explained by women workforce as the value of R-squared shows. The result of study shows that there is higher gender discrimination in the country. Better provision of education to women can remove this wide gap to an extent and improve the socio-economic development of Pakistan.
\end{abstract}

Keywords; Women Workforce Participation, Gross Domestic Product (GDP), Women Education, Socioeconomic development.

DOI: $10.7176 / \mathrm{EJBM} / 11-9-14$

Publication date:March $31^{\text {st }} 2019$

Introduction:

Struggle is the mother of prosperity. Throughout the whole life human being is working to highlight the ends of needs with the colors of progress through every new version of struggle. Since need is the center of each activity and among all the fundamentals of survival, economic requisite is the most important and powerful one, which can cross all barriers and limits. The culture and norms, religion, society and physical borders are not assumed before economic needs. There was a time when one man was responsible for the food, cloth and shelter of his family. As the time go forward, both population and needs increased. The journey of information and technology added comforts in life. Education and awareness agreed people of the world to live with quality. This quality increased standard of living and the perspective naturally controls population to an extent because of limited resources and comparatively better but costly lifestyle. However, with the passage of time, man's capabilities are seeming insufficient even to fulfill the economic requisites. So, the woman, who has the traditional status of caretaker, began to cooperate man. From the family enterprises and working in farms to the organized white-collar jobs, woman is getting professional. In fact, profession is necessity for today's woman. Woman participation in labor force keeps very importance for the growth of a country.

The countries have high rate of women labor force which are under developed or developing. Because in such countries, men are not highly educated. A big percentage of both men and women are working in the blue-collar jobs. Women with manual factory jobs are not accepted by many societies. A man with working wife in such kind of job is seemed as lazy, idle and careless of his family responsibilities. According to Goldin (1995), when development comes in poor countries, industries begin to establish, opportunities for men increases rapidly relative to women. Their wages increase and they are hired in white collar jobs. Women labor force participation declines for the time being. Because progress of husband ultimately benefits his wife. Majority of women prefer to be housewives because they do not have opportunities like men. Moreover, Boserup's (1970) describes in his book on Women and Development that it is due to marginalization of women. When development comes the traditional status of women also emerged such that inequality and gender discrimination increase in the society. After the initial phase of development of country, when GDP per capita rises, the literacy rate increases in the men and women especially. Educated women can do office jobs and other comfortable jobs like teaching. So, highly qualified women turn back to enjoy her favorable time. Basically, education provides awareness and people of the country changes their thoughts, living styles and attitudes. When women join jobs the rate of fertility declines normally. No doubt, fertility rate also depends on many other factors. This is one of the important reason that women labor force participation controls birth rates, (Mammen and Paxson 2000). 
Many times, women are not treated equally with men like in India and in some areas of Pakistan, women are treated very poorly. Their education, health, property rights are demolished due to conservatism. However, investment in women is very profitable. Today's women of Pakistan are not only serving their family but also contributing a great share in the growth of Gross Domestic Product (GDP). According to Mammen and Paxson (2000), there are two determinants or factors which play decisive role in women work force participation. One is the opportunity cost of the women time after education which force them to compromise over the wages and salaries of market against their qualification. Secondly, the income which is not earned by women i.e. income of husband, profits and rental incomes. If incomes not earned by woman are very high and consistently increasing, women labor force participation will decrease. There is an inverse relationship between unearned income of women and women labor force supply.

This article is the case study of Pakistan. Women are playing their roles in different fields. The impact of total women labor force is checked on the growth rate of gross domestic product of the country. In this research paper (9) years (2001-02 to 2012-13) data of women labor force participation has been taken. The growth rate of GDP of Pakistan in the respective years is supposed as dependent variable. In Pakistan women labor is increasing every year. So, the relationship between the two keeps importance for research purpose. In the next section relevant literature has been discussed.

\section{Literature Review:}

The contribution of women workforce in the growth of GDP is studied with many other aspects of the women life which directly or indirectly affect women workforce participation at national and international level of literature.

Zahir, Sharif and Anwar (2009), in their article "The Socio-Economic and Demographic Determinants of Women Work Participation in Pakistan: (Bahawalpur)" discussed the factors responsible for female labor force in Pakistan. They collected the data through field survey in the year (2007-08) for 164 female aged 15-64 years from urban and rural Bahawalpur areas. They considered different explanatory variables i.e. determinants in the operational model. They concluded that variables like education, age, marital status, number of dependents, join family setup, age of children and rural residency have significant positive impacts on the female labor force participation. They said that education is the most important determinant. Female with M.Phil., PHD have highest probability to participate and higher female education is very beneficial for economy and for the society as well. Similarly, female in the age groups (25-34) and (45-55) have very significant impact on the women workforce participation. On the other hand, variables like presence of household assets, household size, spouse participation, urban residency and salary of husband have significant negative impacts on the female labor participation.

Kozel and Alderman (1990) concluded that the possible increase in earnings, level of female education rises the female participation using OLS regression and Tobit model. Likewise, Malik et al. (1994) analyzed and focused on factors like man and woman wage rate, Aly and Quisi (1996) on female wages and her education, Azid et al. (2001) on female age, education and her children along with poverty status. Naqvi and Shahnaz (2002) said that marital status, number of children and lower education inversely related with woman participation. Chaudhry and Nosheen (2009) said about woman empowerment that it is influenced by women job, education, media and culture.

Klasen and lamanna (2009) researched on the impact of gender discrimination in education and employment on the growth of economy for a panel of countries. They present the arguments in favor of woman education and employment with the help of past research and update the situation with their current study. There is the summary of these arguments; talking about gender inequality in education, first, society and economy have less human capital with lower talent because intelligent girls are restricted to get education and do jobs (Dollar and Gatti 1999). And if the returns to education are reducing in the country and girls are not provided higher education while boys are getting higher education it means that the marginal returns to education for woman will be higher than man and can grow the economy (World Bank 2001; Knowles, Lorgelly, and Owen 2002). Secondly, female education reduces fertility, child mortality and encourage education for the upcoming generation [Galor and Weil (1996); Lagerlo"f (2003); World Bank (2001); and King, Klasen, and Porter (2008)]. Arguments in the favor of employment are also there; first, women who are illiterate do not participate in the workforce can become good employer and increase the ability of workforce. Due to gender gap they cannot utilize their talents (Esteve-Volart 2004). Gender inequality causes increase in fertility and thereby reduce economic growth (Cavalcanti and Tavares 2007). Female employment has numerous effects on her own life such that it increases her bargaining power in the home (Amartya Sen [1990]; Lawrence James Haddad, John Hoddinott, and Harold Alderman [1997]; Duncan Thomas [1997]; World Bank [2001]; Stephan Klasen and Claudia Wink [2003]; and King, Klasen, and Porter [2008]) and leads to a better living and health standards of family, increase in investment, savings etc. (Thomas [1997] and World Bank [2001]). Women are not habitual of corruption and favoritism as compare to man (World Bank 2001; Anand Swamy, Omar Azfar, Stephen Knack and Young Lee 2001). Gender gap in education and thereby in employment has significant negative impacts on the gross domestic product according to the Solowgrowth model, (Elizabeth M. King and M. Anne Hill (1993) as well as Knowles, Lorgelly, and Owen (2002). Research on Indian states also suggests that gender gap in managerial positions has notable negative impact on the 
economic growth (Esteve-Volart 2004). Klasen and lamanna (2009) concluded their study with the comments that inn south Asia gender discrimination is seemed both in education and employment. In MENA, gender gap is reduced in education but not in employment. There are structural, cultural, social and ideological hindrances in the countries of MENA (World bank 2004). They find that gender gap reduced economic growth in the early 1990s. This gap is decreasing in the MENA and south Asia and it is expected that the negative effects will also diminish with the time. Keeping in mind that gender inequality is the great barrier for economic growth and a great problem for the new generation.

Bloom, Canning, Fink and Finlay (2009) research on 97 countries of the world covering period of (19602000). They said that female workforce is beneficial for the economy because it increases income per capita and decreases fertility. Male education is inversely related with female participation.

Professor Naila Kabeer said that women face many constraints in labor market participation. The most important problem is the responsibility of women to take care of her children and husband. While a woman is serving her family, she has less possibility of serving market. Moreover, the labor market women are more likely to do formal jobs which are not available in the market generally. Market are also very personal, as the labor is selected based on their race, ethics, class, power relations and sex. Even if jobs are available women are not encouraged to avail the opportunities due to the prevailing gender gap in the society. These all things matter because women participation is a great source of economic growth and women with education and employment not only serves a country but a generation.

\section{Research Methodology}

In this section research methodology, sources of data, variables and hypothesis have been discussed. This paper is about impact of women employment on the growth of gross domestic product.

Data for women workforce participation and the growth of GDP has been taken from "Pakistan Bureau of Statistics, Government of Pakistan". This is nine years data for the period (2001-2013) after excluding these years (2002-03, 2004-05 and 2011-12) as data of women workforce participation for these years is not available in the "Pakistan employment trends 2013, Pakistan bureau of statistics."

The dependent variable is the growth rate of GDP of Pakistan. The explanatory variable is the percentage of women workforce participation for total population of Pakistan. After the thorough study of relevant literature, it has been hypothesized;

"Increase in the rate of women workforce participation in Pakistan has increased the growth rate of gross domestic product for the period (2001-13)."

Statistical techniques have been applied on the data. The next section of study elaborates findings and results.

\section{Results:}

The results of study are expressed in this section. Statistical techniques Like Correlation, Descriptive Statistics and Ordinary Least Square (OLS) are used to know the impact of women workforce participation on the growth of GDP.

The Table no. 1 shows correlation matrix results. Correlation between the GDP growth rate and the rate of increase in women workforce participation is not strong. There is a weak positive relationship between the dependent and independent variables. It may be due the fact that in Pakistan women faces problems in education and employment. Further is important to notify that in Pakistan employment ratio to overall population is only $53.1 \%$ in 2012-13. Of the total labor force $81.1 \%$ are men and $24.3 \%$ are women according to Pakistan statistical bureau. In such a case where gender discrimination is very high as in our study, the correlation value of 0.322 is not bad. Because here the women are not provided direct opportunities like men.

\begin{tabular}{|l|l|l|}
\hline TABLE NO. 1 & GDP growth rate & $\begin{array}{l}\text { Increase in women workforce } \\
\text { participation rate }\end{array}$ \\
\hline CORRELATION MATRIX & 1 & 0.322192 \\
\hline GDP growth rate & 1 & 1 \\
\hline Increase in women workforce participation rate & 0.322192 & \\
\hline
\end{tabular}

The Table No. 2 is about descriptive statistics of dependent and independent variable. The average mean growth rate of GDP is 4.044 and that of increase in the rate of women workforce is 0.889 or approximately $1 \%$ increase. The median values are little different than mean values in both variables. Mean values are more reliable in that case because it includes the effect of every value of growth rate for 9 years period. Maximum value of GDP growth rate is $7.7 \%$ or $8 \%$ in $(2003-04)$, that is two times of mean. The minimum GDP growth rate is 0.36 in (2008-09). The maximum increase in women workforce is $3.1 \%$ in (2005-06) and $-0.1 \%$ minimum value in (201213). The standard deviations of both variables are significant showing that in GDP growth rate about $53 \%$ of values as coefficient of variance calculated, are deviating from mean value. In case of increase in women work force participation standard deviation is 1.05 even higher than mean so in that case it can be said that data is not consistent and rate of change is not constant. In both variables data is asymmetric. The negative skewness of GDP (-0.019) 
shows that mode value higher than mean and the positive skewness of women workforce (1.042) shows that the mean value is higher than mode. The distribution of GDP growth rate is platykurtic and the distribution of women workforce is nearly leptokurtic.

TABLE NO. 2
\begin{tabular}{|l|l|l|}
\hline DESCRIIPTIVE STATISTICS & GDP Growth Rate & $\begin{array}{l}\text { Increase in Women Workforce } \\
\text { Participation Rate }\end{array}$ \\
\hline Mean & 4.044 & 0.889 \\
\hline Median & 3.68 & 0.5 \\
\hline Maximum & 7.7 & 3.1 \\
\hline Minimum & 0.36 & -0.1 \\
\hline Standard deviation & 2.168 & 1.05 \\
\hline Skewness & -0.019 & 1.042 \\
\hline Kurtosis & 2.456 & 3.106 \\
\hline Jarque bera & 0.111 & 1.633 \\
\hline Probability & 0.946 & 0.442 \\
\hline Sum & 36.4 & 8 \\
\hline Sum of square deviation & 37.627 & 8.829 \\
\hline Observations & 9 & 9 \\
\hline
\end{tabular}

The Table No. 3 represents the Ordinary Least Square estimates. The coefficient shows there is a little marginal contribution ( 0.665$)$ of independent variable that is, 'increase in rate of women workforce participation' in the growth of gross domestic product of Pakistan. But confirming the null hypothesis of study that the relationship between women labor force and GDP is positive as the value of coefficient shows. Standard error of coefficient is high relative to coefficient i.e. (0.738), refers that the contribution of women workforce to GDP is not constant. because every year the women work force of Pakistan is not increasing with the same rate. The value of t-statistic (0.900) also implies that the women workforce has not a significant impact on GDP. The probability of t-stats also supports the outcomes.

There is lower value of R-squared. Only $10 \%$ of the GDP of Pakistan is explained by women workforce. The Adjusted R-square value is negative because the independent variable of model is not capable enough to improve the dependent variable. Again, the standard error of regression line is very high (2.195). The values are wider to the fitted line. As it was previously stated that the rate.

\section{OLDINARY LEAST SQUARE METHOD}

Dependent Variable; GDP Growth Rate

Independent Variable; Increase in Women Workforce Participation Rate

Sample: Adjusted Nine Years (2001-13)

\begin{tabular}{|c|c|c|c|c|c|}
\hline \\
\hline Variable & Coefficient & \multicolumn{2}{|c|}{ Standard error } & t-statistic & Probability \\
\hline $\mathrm{C}$ & 3.4532 & \multicolumn{2}{|c|}{0.9830} & 3.5128 & 0.0098 \\
\hline $\begin{array}{l}\text { Independent } \\
\text { variable }\end{array}$ & 0.6651 & \multicolumn{2}{|l|}{0.7387} & 0.9005 & 0.3978 \\
\hline R-square & \multicolumn{2}{|l|}{0.1038} & \multicolumn{2}{|c|}{ Mean dependent variable } & 4.044 \\
\hline Adjusted R-square & \multicolumn{2}{|l|}{-0.0242} & \multicolumn{2}{|c|}{ S.D dependent variable } & 2.1687 \\
\hline S.E of regression & \multicolumn{2}{|l|}{2.1948} & \multicolumn{2}{|c|}{ Akaike info criterion } & 4.6032 \\
\hline Sum squared resid & \multicolumn{2}{|l|}{33.7212} & \multicolumn{2}{|c|}{ Schwarz criterion } & 4.6471 \\
\hline Log likelihood & \multicolumn{2}{|l|}{-18.7145} & \multicolumn{2}{|c|}{ Hannan- Quinn criterion } & 4.5086 \\
\hline F- statistic & \multicolumn{2}{|l|}{0.8108} & \multicolumn{2}{|c|}{ Durbin- Watson criterion } & \multirow[t]{2}{*}{1.9169} \\
\hline Probability (f- stats) & 0.3978 & & & & \\
\hline
\end{tabular}

of increase in women workforce of Pakistan is not regular. The probability of F-statistic (0.3978) promotes the null hypothesis to be accepted.

The mean of GDP growth rate is $4 \%$ per year with a higher standard deviation (2.168). It is because Pakistan is a developing country. Up and down streams in growth are not strange for it. The lower Akaike Information Criterion value (4.6) shows that the quality of model made is good. The Durbin Watson criterion value (1.96) shows a positive serial correlation in the residuals. The values of results are lower than average because in Pakistan women are not basically promoted for employment. All the estimates reveal that there is higher gender discrimination in Pakistan. 
Conclusion and Recommendations:

After the expression of statistical results, it is appropriate to conclude the study with some recommendations for the women of country Pakistan.

Pakistan has a developing economy. It has a male dominated society. The social believes of people do not allow the woman of country to get equal education and employment to man. Due to inadequate education features woman can't economically participate even in the rainy days. Market competition suggests highly educated and confident females. In Pakistan due to gender inequality, the rate of women workforce participation is very low. The growth of this rate is not constant. No doubt previous studies provide strong evidence that women employment perform an important role in the growth of economy. This study also supports the argument and confirms our hypothesis that increase in the rate of women workforce participation has positive impacts on the GDP growth of Pakistan for the selected 9 years period (2001-13). But the relationship is not significant. Because the overall employment to population ratio is around $50 \%$. The women workforce is nearly one fourth of the total labor force. So, the ordinary least square concludes that there is a weak positive relationship between the rate of increase in the women workforce and the growth rate of GDP of Pakistan.

Based on the literature studied and as the case of Pakistan there are some recommendations to improve the women workforce rate.

First, woman in Pakistan should be provided proper higher education. Increase in education rate would probably open opportunities for woman relative to man. Employment is one factor; woman education grows awareness in the society and remove conservatism. It brings comfort in lives. Educated people can solve their problems in a better way. It improves child mortality rate. Nations with higher literacy rate are more civilized ones.

Secondly, women should have a reasonable quota in government and private institutions. Equally treating the gender on merit basis may improve the situation. Lastly, it is strongly believed that women in the coming time period may get favor on the basis of their qualification because of international development projects like China Pakistan Economic Corridor (CPEC).

\section{REFERENCES}

a) Faridi Muhammad Zahir, Chaudhry Imran Sharif and Anwar Mumtaz (2009) "The Socio-Economic and Demographic Determinants of Women Work Participation in Pakistan: Evidence from Bahawalpur District" Research Journal of South Asian Studies Vol. 24, No. 2, pp. 353-369

b) Aly, Y. H., and I. A. Quisi (1996), "Determinants of Women Labor Force Participation in Kuwait: A Logit Analysis", The Middle East Business and Economic Review 8:2.

c) Azid, T., Aslam, M. and Chaudary, M. O. (2001), "Poverty, Female Labor Force Participation, and Cottage Industry: A case study of cloth embroidery in Rural Multan”, The Pakistan Development Review, 40:4, pp 1105-1118.

d) Chaudhry, Imran Sharif and Nosheen, Farhana (2009), "The Determinants of Women Empowerment in Southern Punjab (Pakistan): An Empirical Analysis” European Journal of Social Sciences, 10(2): pp 216-229.

e) Kozel, V., and H. Alderman (1990), "Factors Determining Work Participation and Labor Supply Decisions in Pakistan's Urban Area", The Pakistan Development Review, 29:1, pp 1-18.

f) Malik, et al. (1994), "Determining of women time allocation in selected districts of rural Pakistan", The Pakistan Development Review, 33:4.

g) Naqvi Zareen F. and Lubna Shahnaz (2002), "How do women decide to work in Pakistan?" The Pakistan Development Review, 41(4), Part II: pp 495-513.

h) Goldin Claudia.(1995),“The U-Shaped Female Labor Force Function in Economic Development and Economic History,” in T. Paul Schultz, ed. Investment in Women's Human Capital.

i) Boserup Ester (1970). "Woman's Role in Economic Development”. London: Allen \& Unwin.

j) Mammen Kristin and Paxson Christina (2000) "Women's Work and Economic Development" Journal of Economic Perspectives, Vol:14, No. 4, pp 141-164

k) Stephan Klasen \& Francesca Lamanna (2009) "The Impact of Gender Inequality in Education and Employment on Economic Growth: New Evidence for a Panel of Countries”, Feminist Economics, 15:3, pp 91-132

1) Dollar, David and Roberta Gatti (1999). “Gender Inequality, Income and Growth: Are Good Times Good for Women?' Mimeograph, World Bank, Washington, DC

m) Knowles, Stephen, Paula Lorgelly, and Dorian Owen. (2002). “Are Educational Gender Gaps a Brake on Economic Development? Some Cross-Country Empirical Evidence.’ Oxford Economic Papers 54(1): pp 118-49.

n) Esteve-Volart, Berta. (2004). "Gender Discrimination and Growth: Theory and Evidence from India." STICERD Discussion Papers DEDPS42, London School of Economics

o) Galor, Oded and David N. Weil. (1996), “The Gender Gap, Fertility, and Growth." American Economic Review 86(3): pp374-87. 
p) Cavalcanti, Tiago V. de and Jose' Tavares. (2007), “The Output Costs of Gender Discrimination: A ModelBased Macroeconomic Estimate.’' Mimeograph, University of Lisbon.

q) Swamy, Anand, Omar Azfar, Stephen Knack, and Young Lee. (2001), “Gender and Corruption.” Journal of Development Economics 64(1): pp 25-55.

r) Sen, Amartya. 1990. "Gender and Cooperative Conflicts,"' in Irene Tinker, ed. Persistent Inequalities: Women and World Development, pp. 123-49.

s) Bloom David E, Canning David, Fink Günther and Finlay Jocelyn E. (2009) Fertility, female labor force participation, and the demographic dividend, Springer Journal of Economic Growth, 14: pp79-101

t) Kabeer Naila, "Women's economic empowerment and inclusive growth: labor markets and enterprise development", SIG WORKING PAPER 2012/1, UK"s Department for International Development (DFID) and the International Development Research Centre (IDRC).

u) Government of Pakistan, statistics division, Pakistan bureau of statistics, Pakistan Employment 2013, Macro Economic Indicators; Growth Rates 